and basement lamina seems to be related to endothelial injury only in as far as the basement lamina becomes exposed. We therefore suggested that this intoraction and that between platelet and platelet aro mediated through two fundamentally different mechanisms and should bo thought of as two different phenomena.

J. P. Tranzer

H. R. BaUmgartaker

Department of Experimental Medicine,

F'. Hoffmann-La Roche and Co., T.td.,

Basle, Switzerland.

${ }^{2}$ Baumgartner, H. R., Tranzer, J. P., and Studer, A., Thrombos. Diathes. Haemorth. (in the press).

¿ Born, G. V. R., Vorträge des 4 Freiburger Kolloquiums über Kreislauf-

s Born, G. V. R.. Ann. Roy, Coll. Surg. Enq., 36, 200 (1965).

- Hugues, J., CR Soc. Biol, 154, 806 (1960).

- Erench, J. F., Macfarlane, R. G., and Sanders, A. G., Brit. J. Ktrp. I'athol., 45, 467 (1964).

- Tranzer, J. X'., and Thoenen, H., Experientia, 23, 128 (1967).

\section{Absence of Testosterone in Urine of Rats}

Camacho and Migeon ${ }^{1}$ established that testosterone which had been recovered from the urine of normal subjects was largely conjugated with glucuronic acid. Recently, measurement of testosterone in urine after $\beta$-glucuronidase hydrolysis has been proposed as a satisfactory means of evaluating testicular function ${ }^{2}$ and testosterone production $^{3}$ in male subjects.

Testosterone has beon tentatively identifiod in testicular vonous blood of the adult rat. From this observation, it was suggested that testicular function in the rat could be assessed by the excrotion of testosterono in urine. To test this hypothosis we used the method of de Nicola, Dorfman and Forehielli ${ }^{5}$ to measure testosterone in urine. We modified their method to provide increased sensitivity, precision and specificity. The most important changes were: (1) acotylation of testosterone after paper chromato. graphy, followed by thin-layer chromatography of testostorone acetate on silica gel in ligroin : ethyl acotate (5:2); and (2) addition of cholesterol as an internal standard before gas-liquid chromatography using 3 per cont $O V-1$ and 3 per cent OV-17 as the liquid phasos on separate $6 \mathrm{ft}$. columns. In optimal conditions, $12.5 \mathrm{~m} \mu \mathrm{g}$ of testosterone acetate was detected and measured in biologieal sumples.

The results of our measurements of testostorone in urine aro shown in Table 1. Testosterone was not identifiable after $\beta$-glucuronidase hydrolysis of urine which had been collected from adult rats or from rats which had been given human chorionic gonadotrophin. Urine from a normal male subject and from a male pseudohermaphrodite gave results comparable with those reported by others ${ }^{5,8}$.

An attempt was made to determine whether a testosterone conjugate which could be hydrolysed by acid was prosent in the spent urine from adult male rats. After incubation with $\beta$-glucuronidase and extraction, the spent urine was taken to $\mathrm{pH} 1$ with hydrochloric acid and incubated for $24 \mathrm{~h}$ (ref. 7) and analysed as described. No testosterone could be idontified. We concluded that little or no testosterone was present in the $\beta$-glucuronidase-hydrolysed or $p H$ I fraction of urine from adult male rats or in the fraction from the urine of rats treated with human chorionic gonadotrophin which had been hydrolysed with enzyme.

Fishman and $\mathrm{Sie}^{8}$ demonstrated that slices of rat liver can conjugate testosterones with glueuronic acid in vitro. Comparison
T'able 1. COMPARISON OF TESTOSTERONE RXORUTION IN ORINE OH TIE RAT Table 1. COMPARISON OF TESTOSTERONE EX

\section{Experiment}

'Welve rats (250 g) 200 IU human choronic gonadotrophin daily for 5 days 21 yr
Male pseudoherm-
aphrodite, aged $14 \mathrm{yr}$ Ten rats ( $80 \mathrm{~g})$ Normal man, aged

$\begin{array}{cccc}\begin{array}{c}\text { Time of } \\ \text { urine } \\ \text { collection } \\ \text { (h) }\end{array} & \begin{array}{c}\text { Recovery of } \\ { }^{3} \text { H-testo- } \\ \text { sterone } \\ (\%)\end{array} & \begin{array}{c}\text { Testo- } \\ \text { sterone } \\ \text { measured } \\ (\mu \mathrm{g})\end{array} & \begin{array}{c}\text { Calculated } \\ \text { maximum } \\ \text { testosterone/ } \\ \text { sample }(\mu \mathrm{g})\end{array} \\ 48 & \mathbf{3 1 . 4} & 0 & <0.281 \\ 72 & 27.4 & 0 & <0.347\end{array}$

\section{4}

$43 \cdot 0$

$61 \cdot 6 / 24 \mathrm{~h}$

$66 \cdot 0 / 24 \mathrm{~h}$
$24 \quad 29 \cdot 9$

of the excretion of testosterone by the rat and man indicates that, although testosterone may be a secretory product of the rat testes, it does not seem to be excreted as testosterone glucuronide in the urine of the rat as it is in man.

These studies were supported in part by grants from the National Institutes of Health, US Public Health Servico.

Gutulermo F. Carrera

Roy L. PONTHIER, rUN.

Bernard F. Rice

Division of Endocrine Ressarch, Section II, Alton Ochsner Medical Foundation,

New Orleans, Louisiana.

Received September 18; revised October 9, 1967.

${ }^{1}$ Camacho, A. M., and Migeon, C. J., J. Clin. Invest., 48, 1083 (1964).

${ }^{2}$ Rosner, J. M., and Conte, N. F., J. Clin. Endocrinology, 26, 735 (1966).

' Korenman, S. G., Wilson, H., and Lipsett, M. B., J. Clin. Invest, 42, 1753 (1963).

${ }^{4}$ Hashimoto, I., and Suzuki, Y., Endocrinol. Jap., 13, 326 (1966).

${ }^{\circ}$ de Nicola, A. F., Dorfinan, R. I., and Forchielli, $\mathbf{E}_{4}$, Steroids, 4, 351 (1966).

'Rice, B. F., Cleveland, W. W., Sandberg, D. H., Ahmad, N., Politano, V. T., and Savard, K., J. Clin. Ëndocrinol., 27, 29 (1967).

${ }^{7}$ Dulmanis, A., Coghlan, J. P., Wintour, M., Hudson, B., Aust. J. Exp. Biol. Med. Sci., 42,384 (1964).

"Fishman, W. H, and Sie, H. G., J. Biol, Chem.,218, 335 (1956).

\section{Mode of Early Shell Growth in the Ammonite Promicroceras marstonense Spath}

Some authors have suggested that the nature of the contiguity betwoen the ammonoid proseptum and the shell wall indicates that there is no junction, but that the two are continuous resulting from contemporaneous formation ${ }^{1-3}$. This contrasts with the relationship botween "normal" septa (that is, all septa excluding the proseptum) and the shell wall to which they are attached. There is abundant evidence in the case of "normal" septa that they were secreted by the animal's adapical soft parts to the inner surface of previously formed shell. The

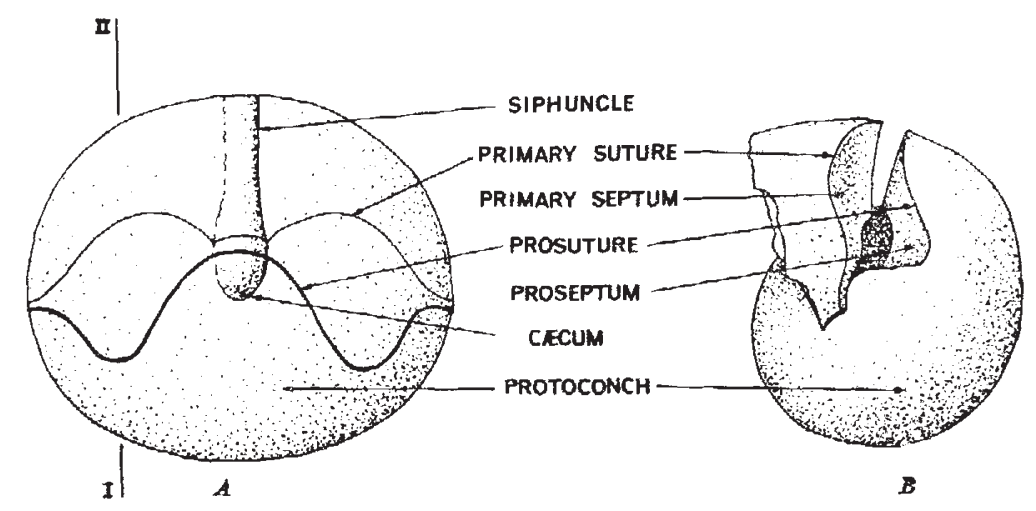

Fig. 1. Internal mould of the protoconch and early chambers of promicroceras marstonense Spath: specimen No. DP 35. A, Ventral view showing the siphuncie and caceum which, although internal, can be scen through the transparent calcite intiling. The line $1-1$ shows the approximate nosition of the secticns illustrated in Fig. 3 . 